\section{String Blossom Thinner Designed for Variable Tree Forms Increases Crop Load Management Efficiency in Trials in Four United States Peach-growing Regions}

\author{
T. Auxt Baugher ${ }^{1,6}$, J. Schupp ${ }^{1}$, K. Ellis ${ }^{1}$, J. Remcheck ${ }^{1}$, \\ E. Winzeler ${ }^{1}$, R. Duncan ${ }^{2}$, S. Johnson ${ }^{2}$, K. Lewis ${ }^{3}$, G. Reighard ${ }^{4}$, \\ G. Henderson ${ }^{4}$, M. Norton ${ }^{2}$, A. Dhaddey ${ }^{5}$, and P. Heinemann ${ }^{1}$
}

AdDitional Index wORDs. Prunus persica, mechanical bloom thinning, thinning, training, quality, set, labor, stone fruit

SUMMARY. Hand thinning is a necessary and costly management practice in peach (Prunus persica) production. Stone fruit producers are finding it increasingly difficult to find a workforce to manually thin fruit crops, and the cost of farm labor is increasing. A new "hybrid" string thinner prototype designed to adjust crop load in vase or angled tree canopies was evaluated in processing and fresh fruit plantings in varying production systems in four U.S. growing regions in 2009. Data were uniformly collected across regions to determine blossom removal rate, fruit set, labor required for follow-up green fruit hand thinning, fruit size distribution at harvest, yield, and economic impact. String thinner trials with the variable tree forms demonstrated reduced labor costs compared with hand-thinned controls and increased crop value due to a larger distribution of fruit in marketable and higher market value sizes. Blossom removal ranged from $17 \%$ to $56 \%$, hand thinning requirement was reduced by $19 \%$ to $100 \%$, and fruit yield and size distribution improved in at least one string-thinning treatment per experiment. Net economic impact at optimum tractor and spindle speeds was $\$ 462$ to $\$ 1490$ and $\$ 264$ to $\$ 934$ per acre for processing and fresh market peaches, respectively. Case study interviews of growers who thinned a total of 154 acres indicated that commercial adoption of stringthinning technology would likely have positive impacts on the work place environment.

This research was supported by the U.S. Department of Agriculture Specialty Crop Research Initiative, by the California Canning Peach Association, by the Washington Tree Fruit Research Commission, by the State Horticultural Association of Pennsylvania, by the South Carolina Peach Council, and by the Pennsylvania Peach and Nectarine Board.

We acknowledge the valuable contributions of $\mathrm{K}$. Reichard, J. Koan, C. Musselman, A. Leslie, R. Rohrbaugh, R. Dise, C. Anders, E. Moore, C. Kuntz, T. Salada, E. Anderson, F. Showers, T. Baker, K. Mickley, B. Jarjour, A. Betz, S. Betz, D. Kilmer, J. Cline, S. Aguilar, J. Lott, D. Kuhn, R. Lamb, S. Kuhn, D. Mickey, J. Mickey, D. Wenk, B. Wenk, J. Wenk, E. Rankin, A. Dias, C. Baugher, D. Lott, C. McCleaf, M. Rice, D. Slaybaugh, B. Knouse, D. Van Konynenburg, P. Van Konynenburg, R. Orozco, C. Carr, III, J. Rodgers, J.W. Yonce and Sons, J.A. Watson and Sons, N. Kline, S. Johl, K Bains, I. Pagani, T. Webb, K. Warda, I. Hanrahan, T. Schmidt, F. Castillo, D. Henan, and R. Valicoff.

The mention of a trademark, proprietary product, or vendor does not constitute a guarantee or warranty of the product and does not imply its approval to the exclusion of other products or vendors that also may be suitable.

${ }^{1}$ The Pennsylvania State University, 670 Old Harrisburg Road, Gettysburg, PA 17325

${ }^{2}$ University of California Cooperative Extension, Crows Landing, Modesto, CA 95358

${ }^{3}$ Washington State University, P.O. Box 37, Ephrata, WA 98823

${ }^{4}$ Clemson University, College of Agriculture, Clemson, SC 29634

${ }^{5}$ California Canning Peach Association, 2300 River Plaza Drive, Sacramento, CA 95833

${ }^{6}$ Corresponding author. E-mail: tab36@psu.edu.

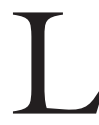
abor utilization and availability are of great concern to specialty crop growers. Many of the current labor-intensive activities required in the production of specialty crops will need to be replaced by more mechanized and automated techniques. Glozer and Hasey (2006) estimated that hand-thinning labor represents $31 \%$ of all cultural costs associated with cling peach production, with labor requirements ranging from 25 to over $100 \mathrm{~h} /$ acre. Estimates for other fresh fruit peach cultivars are similar (Krawczyk, 2010). The availability and efficacy of chemical-thinning programs varies by crop, orchard, and season, thus followup hand thinning is often required to adjust crop load for optimal fruit size, quality, and to promote return bloom. This is particularly true for stone fruit, where chemical-thinning options are limited and unpredictable.

Mechanical-thinning devices that were tested on peach trees in the past included trunk shakers (Berlage and Langmo, 1982), low-frequency electrodynamic limb shakers (Diezma and Rosa, 2005; Glozer and Hasey, 2006), high-pressure water streams (Byers, 1990), rotating rope curtains (Baugher et al., 1991), and spiked drum shaker fruit removal systems (Glenn et al., 1994). None of the thinning mechanisms were widely adopted by the stone fruit industry due to lack of uniform thinning, insufficient economic incentive, or adverse effects on fruit size.

A mechanical string thinner designed to thin apple (Malus $\times$ domestica) blossoms in organic orchards was tested on peach trees for the first time in 2007 (Schupp et al., 2008). The string thinner evaluated in 2007 was designed to thin narrow vertical canopies; therefore, it was evaluated on peach trees trained to perpendicular $\mathrm{V}$ or quadrilateral $\mathrm{V}$ systems. As many peach orchards are trained to open-center or vase systems, an over-tree, horizontal string thinner prototype was evaluated in 2008 (Baugher et al., 2009). Peach blossom removal in upper canopy regions ranged from $23 \%$ to $69 \%$, with the new string thinner oriented in a horizontal or inclined position to thin the tops of vaseshaped trees. Optimal thinning with the horizontal string thinner was with a 1.0 mph tractor speed, reducing peach crop load by an average of $47 \%$, reducing follow-up hand thinning time $32 \%$, and increasing fruit in higher market size categories $22 \%$ to $31 \%$. Net economic impact (realized economic savings) of mechanical thinning versus

\begin{tabular}{llll}
\hline $\begin{array}{l}\text { Units } \\
\text { To convert U.S. to SI, } \\
\text { multiply by }\end{array}$ & U.S. unit & SI unit & $\begin{array}{l}\text { To convert SI to U.S., } \\
\text { multiply by }\end{array}$ \\
\hline 0.4047 & acre $(\mathrm{s})$ & $\mathrm{ha}$ & 2.4711 \\
0.3048 & $\mathrm{ft}$ & $\mathrm{m}$ & 3.2808 \\
2.54 & inch(es) & $\mathrm{cm}$ & 0.3937 \\
25.4 & inch(es) & $\mathrm{mm}$ & 0.0394 \\
6.4516 & inch & $\mathrm{cm}^{2}$ & 0.1550 \\
0.4536 & lb & $\mathrm{kg}$ & 2.2046 \\
1.6093 & mph & $\mathrm{km} \cdot \mathrm{h}^{-1}$ & 0.6214 \\
2.2417 & ton/acre & $\mathrm{Mg} \cdot \mathrm{ha}^{-1}$ & 0.4461
\end{tabular}


hand thinning alone ranged from $\$ 323$ to $\$ 368$ per acre. Total yield was sometimes reduced by string thinner treatments; however, high market value yields were comparable across treatments.

The goal of peach blossom thinning research conducted in 2009 was to determine if a new string thinner prototype designed to thin vase or angled tree canopies could be adapted for varying orchard systems in four peach growing regions of the U.S. Trials with the "hybrid" mechanical blossom string thinner were performed in California, South Carolina, Washington, and Pennsylvania commercial orchards. Data were uniformly collected across regions to determine blossom removal rate, fruit set, labor required for follow-up hand thinning, fruit size distribution at harvest, yield, and economic impact. Case study interviews were conducted to assess sociological implications relative to grower adoption.

\section{Materials and methods}

Mechanical STRING THINNER DESCRIPTION. The 2009 string thinner prototype is a hybrid of a vertical rotating string thinner (Darwin 300; Fruit-Tec, Deggenhausertal, Germany) designed by $\mathrm{H}$. Gessler to remove apple blossoms in organic orchards (Bertschinger et al., 1998) and a horizontal prototype evaluated in 2008 peach thinning trials (Baugher et al., 2009). The hybrid string thinner has a $2.5-\mathrm{m}$-long spindle that can be oriented in a vertical or a horizontal position and tilts $30^{\circ}$ in either direction from center (Fig. 1). To permit greater extension into the tree canopy, the strings attached to the spindle are rows of molded hollow cords (Fig. 2) (rather than the coiled plastic cords used with earlier versions of the thinner). String length is 20 inches. The spindle is turned by a hydraulic motor, and speed is adjusted by a proportional flow control valve. The height and angle of the frame supporting the spindle are adjustable to conform to the height and inclination of the tree canopy, and the intensity of thinning is adjustable by changing the spindle rotation speed, the tractor speed, and the string arrangement. Two rows of molded cords were used in each trial, and they were arranged with alternating gaps (Fig. 2A). Depending on production system and bloom density,

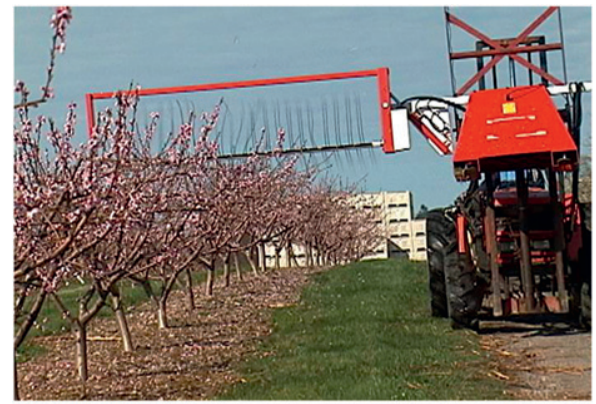

A

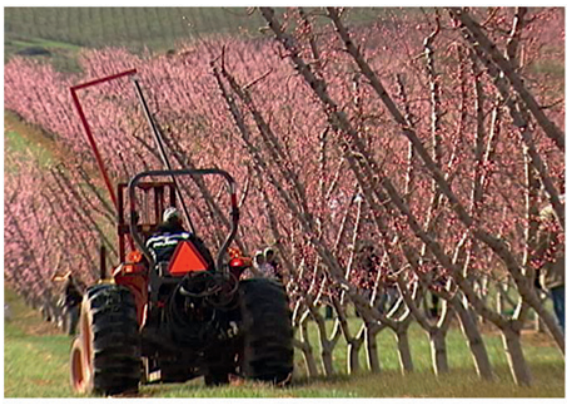

B

Fig. 1. Hybrid string blossom thinner prototype evaluated in 2009 in four peach production regions. The height and angle of the spindle are adjustable to conform to the height (A) and form (B) of the tree canopy, and the intensity of thinning is adjustable by changing the rotation speed, the tractor speed, and the string arrangement (photograph by $\mathrm{M}$. Wherley).

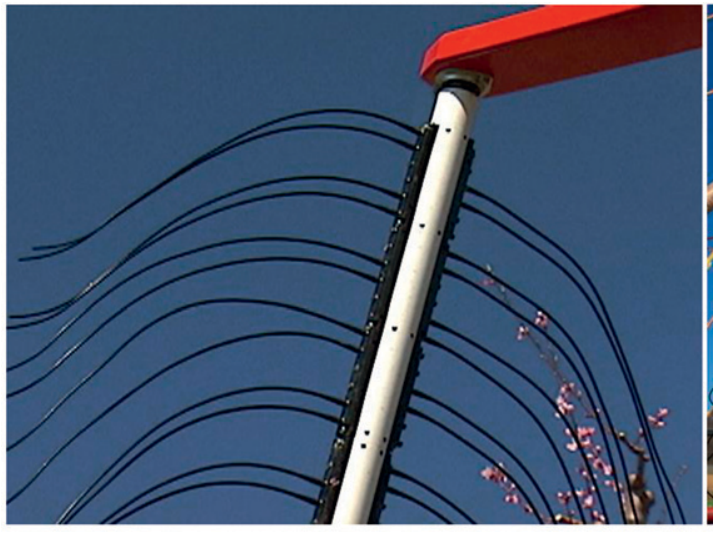

A

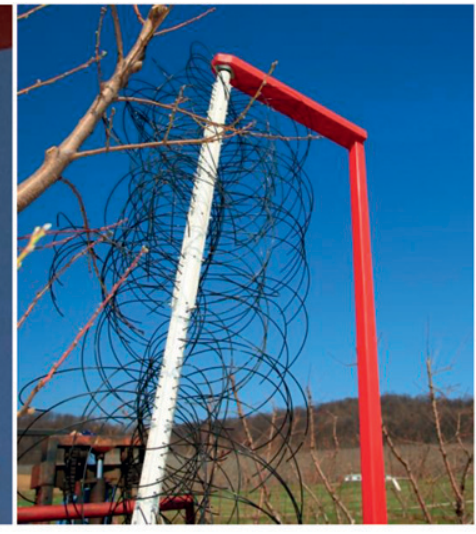

B

Fig. 2. Molded hollow cords (A) tested in 2009 permitted greater extension into the peach tree canopy than the coiled plastic cords (B) used with earlier thinner prototypes (photograph by M. Wherley and S. Hollabaugh).

rotation speed ranged between 150 and $250 \mathrm{rpm}$, and tractor speed ranged from 1.5 to $3.0 \mathrm{mph}$.

COMMERCIAL ORCHARD TRIALS CONDUCTED IN FOUR PEACH PRODUCTION REgIONS. Trials with the 2009 hybrid string blossom thinner prototype were conducted in California, South Carolina, Washington, and Pennsylvania in three canning peach orchards and three fresh fruit peach plantings. Canopies were angled at $60^{\circ}$ to $70^{\circ}$ with two (perpendicular $\mathrm{V}$ ) or four (quad V) main scaffolds. Tree architecture varied by region and market destination. In four plantings, the string thinner spindle was oriented to thin the sides of the trees, and in two perpendicular $\mathrm{V}$ canning peach blocks, the spindle thinned the sides followed by the tops of the trees. Where both the sides and tops of the trees were thinned, alternating strings were shortened by one-third. The cultivars were Tuolumne, Loadel, and Late Ross canning peach (California); Saturn peento (donut-shaped) peach (Pennsylvania); Grand Bright nectarine [Prunus persica (Washington)]; and Nesstar fresh peach (South Carolina). The experimental design in each trial was randomized complete block, with six blocks and multiple-tree plots (two blocks in 'Nesstar' due to delayed shipping of the thinner). Data were collected from two to eight center trees in each plot. The mechanical treatments in all trials were compared with hand thinning at 35 to $40 \mathrm{~d}$ after full bloom (DAFB) and/or hand blossom thinning. String thinning was performed at bloom stages ranging from pink bud to fruit set. 
The stage of flower/fruit development was recorded.

Flower density and crop load were determined on three pre-tagged hangers (processing peaches) or one pretagged scaffold (fresh market peaches) on each of the test trees. Initial blossom density ranged from 8.7 flowers/ $\mathrm{cm}^{2}$ limb cross-sectional area in 'Grand Bright' to 66 flowers $/ \mathrm{cm}^{2}$ limb crosssectional area in 'Tuolumne'. Blossom removal with mechanical thinners was evaluated by counting all or a section of blossoms in the upper and lower canopy regions of the tagged hangers and scaffolds immediately before and after thinning. Reduction in fruit set was evaluated the day of thinning and again following physiological drop (35-40 DAFB) by calculating the number of blossoms or fruit per limb cross-sectional area in the upper canopy and the lower canopy. All trees were uniformly hand thinned by growers to commercial levels, during which follow-up hand thinning time was recorded. At harvest, a sample of 40 to 50 firm-ripe fruit collected from the center trees in each plot ('Tuolumne', 'Loadel', 'Saturn', and 'Grand Bright') was evaluated for mean fruit diameter and fruit size distribution. In the processing cultivars and 'Nesstar', fruit from each plot were weighed and graded at the processing or packing facility, respectively. In 'Grand Bright' and 'Saturn', yields were calculated from fruit per scaffold counts and percentage size distribution. All data were subjected to an analysis of variance and treatments were separated using Fisher's protected least significant difference test.

ECONOMIC AND TECHNOLOGY ADOPTION IMPLICATIONS. Economic partial budget analyses were performed to evaluate the potential impact of each thinning treatment on fruit returns. Mechanical-thinning costs, based on a 15-year useful life of equipment and an $8 \%$ interest rate averaged $\$ 15 /$ acre for the string thinner, including tractor cost $(\$ 12.00 / \mathrm{h})$ and labor $(\$ 12.00 / \mathrm{h})$. Realized economic savings were calculated from follow-up hand-thinning time, fruit size distributions, and average yields. Follow-up hand-thinning costs were based on a labor rate of $\$ 11.20 / \mathrm{h}$ in California, $\$ 10.00 / \mathrm{h}$ in Washington, $\$ 8.50 / \mathrm{h}$ in Pennsylvania, and $\$ 7.25$ / $\mathrm{h}$ in South Carolina. Current commercial prices for the various size categories for each cultivar were obtained from the California Canning Peach Association (processed fruit) or the USDA Agricultural Marketing Service Report (USDA, 2009). All the Pennsylvania growers who tested the mechanical thinner in 2009 agreed to participate in case study interviews to report observations relative to stakeholder adoption. These growers had cooperated in demonstrations on a total of 154 acres.

Table 1. Peach and nectarine blossom thinning and fruit set response to string thinner compared with hand-thinned control treatments in uniformly designed trials in California (CA), Pennsylvania (PA), Washington (WA), and South Carolina (SC) in 2009.

\begin{tabular}{|c|c|c|c|}
\hline Thinning treatment ${ }^{\mathrm{z}}$ & $\begin{array}{c}\text { Blossoms } \\
\text { removed (\%) }\end{array}$ & $\begin{array}{c}\text { Flower density after } \\
\text { thinning (flowers } / \mathrm{cm}^{2} \operatorname{limb} \\
\text { cross-sectional area) }\end{array}$ & $\begin{array}{l}\text { Crop load (density) } \\
\text { at } 35 \text { DAFB (fruit } / \mathrm{cm}^{2} \operatorname{limb} \\
\text { cross-sectional area) }\end{array}$ \\
\hline \multicolumn{4}{|c|}{ 'Tuolumne' canning peach Perpendicular V training, CA } \\
\hline Hand-thinned control, 35 DAFB & 0 & $66.0 \mathrm{a}$ & $34.0 \mathrm{a}$ \\
\hline \multicolumn{4}{|c|}{ 'Loadel' canning peach Perpendicular V training, CA } \\
\hline \multicolumn{4}{|c|}{ 'Late Ross' canning peach Quad V training, CA } \\
\hline String thinner, $80 \% \mathrm{FB} 185 \mathrm{rpm}, 1.5 \mathrm{mph}$ & 20 & - & $21.9 \mathrm{a}$ \\
\hline String thinner, $80 \%$ FB $200 \mathrm{rpm}, 2.0 \mathrm{mph}$ & 18 & - & $26.0 \mathrm{a}$ \\
\hline String thinner, $80 \%$ FB $200 \mathrm{rpm}, 2.5 \mathrm{mph}$ & 17 & - & $26.1 \mathrm{a}$ \\
\hline Hand-thinned control, 35 DAFB & 0 & - & $32.3 \mathrm{a}$ \\
\hline String thinner, pink $225 \mathrm{rpm}, 3.0 \mathrm{mph}$ & $53 \mathrm{a}$ & $5.6 \mathrm{bc}$ & $2.4 \mathrm{c}$ \\
\hline String thinner, $60 \%$ FB $225 \mathrm{rpm}, 3.0 \mathrm{mph}$ & $22 \mathrm{~b}$ & $6.8 \mathrm{~b}$ & $2.2 \mathrm{c}$ \\
\hline String thinner, fruit set $225 \mathrm{rpm}, 3.0 \mathrm{mph}$ & $29 \mathrm{~b}$ & $6.6 \mathrm{~b}$ & $3.5 \mathrm{~b}$ \\
\hline Hand-thinned control, FB & $50 \mathrm{a}$ & $4.2 \mathrm{c}$ & - \\
\hline Hand-thinned control, $35 \mathrm{DAFB}$ & 0 & $8.7 \mathrm{a}$ & $6.1 \mathrm{a}$ \\
\hline \multicolumn{4}{|c|}{ 'Nesstar' fresh peach Quad V training, SC } \\
\hline String thinner, petal fall $200 \mathrm{rpm}, 1.8 \mathrm{mph}$ & $36 \mathrm{~b}$ & $24.6 \mathrm{a}$ & - \\
\hline String thinner, petal fall $220 \mathrm{rpm}, 1.8 \mathrm{mph}$ & 56 a & $14.9 \mathrm{~b}$ & - \\
\hline Hand-thinned control, 35 DAFB & 0 & $31.0 \mathrm{a}$ & - \\
\hline
\end{tabular}




\section{Results and discussion}

BLOSSOM REMOVAL, FLOWER DENSITY, AND FRUIT SET RESPONSES. Blossom removal in plots thinned by the hybrid string thinner ranged from $18 \%$ to $56 \%$, with an average of $36 \%$ across experiments (Table 1). The experiments with the highest levels of blossom removal were the 'Tuolumne' and 'Loadel' in which the mechanical thinner was used to thin the sides and the tops of the trees. The string thinner reduced flower density (flowers $/ \mathrm{cm}^{2}$ limb cross-sectional area) compared with the nonthinned control in the canopies of all cultivars, except Nesstar, thinned at 220 versus $200 \mathrm{rpm}$ (Table 1). In the 'Grand Bright' nectarine experiment, flower density in the plots thinned at the pink stage of bloom was equal to that in the hand blossom-thinned control plots, and later string thinning at $60 \%$ full bloom (FB) or fruit set also reduced flower density compared with the control. Crop load (fruit $/ \mathrm{cm}^{2}$ limb cross-sectional area), measured at 35 to 40 DAFB and before followup hand thinning, was reduced by mechanical thinning in 'Tuolumne', 'Loadel', 'Saturn', and 'Grand Bright', but not in 'Late Ross'. The grower cooperators made the decisions on how many blossoms to remove in each experiment, weighing anticipated impacts on yield and fruit size.

FOLLOW-UP HAND THINNING COMPARISONS. The hybrid string thinner reduced follow-up hand thinning time in all experiments compared with green fruit thinning alone (handthinned control, 35-40 DAFB) (Table $2)$. The percentage of reduction in hand-thinning time ranged from 19\% to $40 \%$ in the processing peach trials and $38 \%$ to $100 \%$ in the fresh peach trials, with the exception of the 'Grand Bright' treatment plots where thinning was conducted at fruit set. The reduction in hand-thinning time at this post-bloom stage of 'Grand Bright' was only 17\%. The poorest follow-up hand-thinning response in processing trials was when the tractor speed was increased to $2.5 \mathrm{mph}$ versus 1.5 or $2.0 \mathrm{mph}$. The associated reductions in hand-thinning costs were \$297/acre for 'Tuolumne', \$386/ acre for 'Loadel', $\$ 128 /$ acre for the $2.0 \mathrm{mph}$ treatment in 'Late Ross', $\$ 55 /$ acre for the $2.5 \mathrm{mph}$ treatment in 'Late Ross', \$308/acre for 'Saturn',
$\$ 198 /$ acre for the pink treatment in 'Grand Bright', \$84/acre for the fruit set treatment in 'Grand Bright', and $\$ 83$ to $\$ 100$ per acre in 'Nesstar' (Table 3). The labor cost for hand blossom thinning followed by green fruit thinning was $\$ 206 /$ acre higher than the green fruit-thinned control.

FRUIT SIZE AND YIELD COMPARISONS. Peach and nectarine fruit size, size distribution, and market value were increased by the string thinner treatments. Mean fruit diameter increased in string-thinned plots compared with hand-thinned plots in the 'Tuolumne' and 'Saturn' experiments, but not in the 'Grand Bright' experiments. The percentage of fruit in number 1 grade increased in the processing plantings, the percentage greater than $23 / 4$ inches in diameter increased in the peento peach planting, and the percentage greater than 3 inches in diameter increased in the 'Grand Bright' plots thinned at pink and the 'Nesstar' thinned at petal fall (Table 4). Marketable size of processing grade number 1 was a fruit diameter greater than or equal to $23 / 8$ inches in diameter plus up to $10 \%$ of fruit $2 \frac{1}{4}$ inches (number 2 grade), depending on cultivar. High market value fresh fruit were all fruit greater than or equal to 3 inches in diameter, with the exception of peento peaches, which were all fruit greater than or equal to $2 \frac{3}{4}$ inches in diameter. Yield of marketable and high market valuefruit increased compared with handthinned control treatments with at least one string thinner treatment in five of the six experiments. Total yield was increased by string thinner treatments in the 'Tuolumne', 'Saturn', and 'Grand Bright' experiments, and in no string thinner treatments was yield reduced. In our 2008 mechanical-thinning research (Baugher et al., 2009), yield was reduced by some treatments; therefore, 2009 cooperating growers monitored blossom density to avoid similar reductions. Yields in the South Carolina trial were reduced due to hail damage.

Table 2. Follow-up hand thinning time required in string thinner compared with hand-thinned control treatments in uniformly designed peach and nectarine trials in California (CA), Pennsylvania (PA), Washington (WA), and South Carolina (SC) in 2009.

\begin{tabular}{|c|c|}
\hline \multicolumn{2}{|c|}{ Hand thinning at 35-40 DAFB } \\
\hline Thinning treatment ${ }^{\mathrm{z}}$ & (h/acre) \\
\hline \multicolumn{2}{|c|}{ 'Tuolumne' canning peach Perpendicular V training, $C A$} \\
\hline String thinner, petal fall $250 \mathrm{rpm}, 1.5 \mathrm{mph}$ & $92.1 b^{x}$ \\
\hline Hand-thinned control, 35 DAFB & $118.5 \mathrm{a}$ \\
\hline \multicolumn{2}{|c|}{ 'Loadel' canning peach Perpendicular V training, CA } \\
\hline String thinner, 60\% FB $200 \mathrm{rpm}, 1.5 \mathrm{mph}$ & $91.7 \mathrm{~b}$ \\
\hline Hand-thinned control, 35 DAFB & $126.2 \mathrm{a}$ \\
\hline \multicolumn{2}{|c|}{ 'Late Ross' canning peach Quad V training, CA } \\
\hline String thinner, $80 \%$ FB $185 \mathrm{rpm}, 1.5 \mathrm{mph}$ & $22.0 \mathrm{c}$ \\
\hline String thinner, $80 \% \mathrm{FB} 200 \mathrm{rpm}, 2.0 \mathrm{mph}$ & $19.2 \mathrm{c}$ \\
\hline String thinner, $80 \%$ FB $200 \mathrm{rpm}, 2.5 \mathrm{mph}$ & $25.8 \mathrm{~b}$ \\
\hline Hand-thinned control, 35 DAFB & $30.7 \mathrm{a}$ \\
\hline
\end{tabular}

'Saturn' peento peach Perpendicular V training, PA

String thinner, pink $150 \mathrm{rpm}, 1.8 \mathrm{mph}$

$18.5 \mathrm{~b}$

Hand-thinned control, 35 DAFB

$37.5 \mathrm{a}$

'Grand Bright' nectarine Perpendicular V training, WA

String thinner, pink $225 \mathrm{rpm}, 3.0 \mathrm{mph}$

String thinner, 60\% FB $225 \mathrm{rpm}, 3.0 \mathrm{mph}$

String thinner, fruit set $225 \mathrm{rpm}, 3.0 \mathrm{mph}$

46.6

$53.2 \mathrm{~b}$

Hand-thinned control, FB

Hand-thinned control, 35 DAFB

$22.1 \mathrm{~d}$

$62.4 \mathrm{a}$

'Nesstar' fresh peach Quad V training, SC

String thinner, petal fall $200 \mathrm{rpm}, 1.8 \mathrm{mph}$

$36.8 \mathrm{~b}$

String thinner, petal fall $220 \mathrm{rpm}, 1.8 \mathrm{mph}$

$34.5 \mathrm{~b}$

Hand-thinned control, 35 DAFB

$48.3 \mathrm{a}$

${ }^{\mathrm{z}}$ String thinner was fitted with two rows of molded cords with alternating gaps; DAFB $=$ days after full bloom, FB = full bloom, $1 \mathrm{mph}=1.6093 \mathrm{~km} \cdot \mathrm{h}^{-1}$.

y $1 \mathrm{~h} /$ acre $=2.4711 \mathrm{~h} \cdot \mathrm{ha}^{-1}$

'Mean separation within cultivars by Fisher's protected least significant difference at $P \leq 0.05$. 
Table 3. Follow-up hand thinning cost, thinning savings, and net economic impact as affected by string thinner treatments in uniformly designed peach and nectarine orchard trials in California (CA), Pennsylvania (PA), Washington (WA), and South Carolina (SC) in 2009.

\begin{tabular}{|c|c|c|c|}
\hline Thinning treatment ${ }^{\mathrm{z}}$ & $\begin{array}{l}\text { Follow-up } \\
\text { hand thinning } \\
\text { cost }(\$ / \text { acre })^{\mathrm{y}}\end{array}$ & $\begin{array}{c}\text { Gross income } \\
(\$ / \text { acre })^{x}\end{array}$ & $\begin{array}{c}\text { Net economic } \\
\text { impact }(\$ / \text { acre })^{\mathrm{w}}\end{array}$ \\
\hline \multicolumn{4}{|c|}{ 'Tuolumne' canning peach Perpendicular V training, CA } \\
\hline Hand-thinned control & 1328 & 8173 & - \\
\hline \multicolumn{4}{|c|}{ 'Loadel' canning peach Perpendicular V training, CA } \\
\hline \multicolumn{4}{|c|}{ 'Late Ross' canning peach Quad V training, $C A$} \\
\hline String thinner, $80 \% \mathrm{FB} 185 \mathrm{rpm}, 1.5 \mathrm{mph}$ & 247 & 5120 & 236 \\
\hline String thinner, $80 \% \mathrm{FB} 200 \mathrm{rpm}, 2.0 \mathrm{mph}$ & 216 & 4267 & $(648)$ \\
\hline String thinner, $80 \% \mathrm{FB} 200 \mathrm{rpm}, 2.5 \mathrm{mph}$ & 289 & 5459 & 462 \\
\hline Hand-thinned control, 35 DAFB & 344 & 4997 & - \\
\hline String thinner, pink $225 \mathrm{rpm}, 3.0 \mathrm{mph}$ & 426 & 12,288 & 847 \\
\hline String thinner, $60 \% \mathrm{FB} 225 \mathrm{rpm}, 3.0 \mathrm{mph}$ & 475 & 11,962 & 472 \\
\hline String thinner, fruit set $225 \mathrm{rpm}, 3.0 \mathrm{mph}$ & 540 & 11,846 & 291 \\
\hline Hand-thinned control, FB & 830 & 12,058 & $(206)$ \\
\hline Hand thinned control, $35 \mathrm{DAFB}$ & 624 & 11,630 & - \\
\hline \multicolumn{4}{|c|}{ 'Nesstar' fresh peach Quad V training, SC } \\
\hline String thinner, petal fall $200 \mathrm{rpm}, 1.8 \mathrm{mph}$ & 280 & 7319 & 264 \\
\hline String thinner, petal fall $220 \mathrm{rpm}, 1.8 \mathrm{mph}$ & 263 & 5097 & $(241)$ \\
\hline Hand-thinned control, 35 DAFB & 363 & 7153 & - \\
\hline
\end{tabular}

${ }^{z}$ String thinner was fitted with two rows of molded cords with alternating gaps; DAFB $=$ days after full bloom before follow-up hand thinning, $\mathrm{FB}=$ full bloom, $1 \mathrm{mph}=1.6093$ $\mathrm{km} \cdot \mathrm{h}^{-1}$.

${ }^{y}$ Follow-up hand thinning cost is based on a labor rate of $\$ 11.20 / \mathrm{h}$ in California, $\$ 10.00 / \mathrm{h}$ in Washington, $\$ 8.50 / \mathrm{h}$ in Pennsylvania, and $\$ 7.25 / \mathrm{h}$ in South Carolina; $\$ 1 /$ acre $=$ $\$ 2.4711$ /ha.

xThinning savings includes reduced follow-up hand thinning inputs and added mechanical thinner, tractor, and tractor operator inputs (also additional hand thinning cost for hand blossom-thinned control). Mechanical thinner cost is based on a 15 -year useful life of equipment and $8 \%$ interest rate. Tractor cost is $\$ 12.00 / \mathrm{h}$; equipment operator cost is $\$ 12.00 / \mathrm{h}$. Market prices for each region obtained from the California Canning Peach Association (processed fruit) or the USDA Agricultural Marketing Service Report [fresh fruit (USDA, 2009)].

wNet economic impact (realized economic savings) is defined as cost/benefit beyond hand thinning alone and takes into account reduced hand thinning inputs and increased value of fruit in higher size categories. Values in parentheses are negative.

ECONOMIC AND TECHNOLOGY ADOPTION IMPLICATIONS. The savings in hand-thinning requirement and increases in fruit size distribution realized in all trials increased the economic value of the peach crops beyond that of hand thinning alone (Table 3 ). Gross income ranged from $\$ 4,267$ to $\$ 9,127$ per acre in processing plantings and $\$ 5,097$ to $\$ 12,288$ per acre in fresh fruit plantings. Net positive economic impact from mechanical thinning (realized economic savings beyond hand thinning alone) ranged from $\$ 236$ to $\$ 1490$ per acre and $\$ 264$ to $\$ 934$ per acre, respectively, with the exception of one treatment in 'Late Ross' and 'Nesstar' in which the economic impact was negative. Economic impact also was negative in the hand blossom-thinned control treatment. The cost-benefit results are consistent with those reported in research on previous string thinner prototypes (Baugher et al., 2009; Schupp et al., 2008). Increased fruit size had a greater positive impact for fresh market producers, while labor savings and yield increases (due to larger fruit size) were of greater importance for canning peach growers.

Case study interviews of 11 Pennsylvania growers and orchard managers who had thinned a total of 154 acres suggested that commercial adoption of mechanical stringthinning technology would have positive impacts on the work place. All case study cooperators reported that blossom string thinning impacted orchard management by making crop load management more efficient and by reducing follow-up hand-thinning time. Eighty percent of the growers noted that fruit from thinned trees were larger. Additional observations included the following: 1) hand thinning of peaches was completed earlier, allowing more timely work in other crops; 2) employees were satisfied with mechanical thinning, as it saved them time and minimized ladder use; and 3) the seasonal distribution of labor-intensive work was improved.

The research results across four peach-growing regions suggest that future trials with the string blossom thinner should focus on increasing access to the peach tree canopy. Sensors and controls that would allow automatic positioning of the spindle could potentially increase the accuracy of thinning. Modifications to tree canopy architecture also should be investigated. The string thinner hybrid 
Table 4. Peach and nectarine fruit size, size distribution, and high market value yield as affected by string thinner treatments in uniformly designed trials in California (CA), Pennsylvania (PA), Washington (WA), and South Carolina (SC) in 2009.

\begin{tabular}{|c|c|c|c|c|}
\hline \multicolumn{5}{|c|}{ Fruit in high market value size categories ${ }^{x}$} \\
\hline Thinning treatment $\mathrm{t}^{\mathrm{z}}$ & $\begin{array}{cc} & \text { Fruit } \geq 23 / 8 \\
\text { Fruit } & \text { inches (canning) } \\
\text { diam }(\mathrm{cm})^{\mathrm{y}} & (\%)\end{array}$ & $\begin{array}{c}\text { Fruit } \geq 3 \\
\text { inches } \\
(\text { fresh })(\%)\end{array}$ & $\begin{array}{l}\text { Total yield } \\
\text { (tons/acre) }^{\mathrm{w}}\end{array}$ & $\begin{array}{c}\text { Yield of high } \\
\text { market value size } \\
\text { fruit (tons } / \text { acre) }\end{array}$ \\
\hline
\end{tabular}

'Tuolumne' canning peach Perpendicular $V$ training, $C A$

String thinner, petal fall $250 \mathrm{rpm}, 1.5 \mathrm{mph}$

$6.6 \mathrm{a}^{\mathrm{u}} \quad 97.2 \mathrm{a}$

$6.3 \mathrm{~b} \quad 94.0 \mathrm{~b}$

$28.7 \mathrm{a}$

27.8 a

Hand-thinned control, 35 DAFB

'Loadel' canning peach Perpendicular V training, CA

String thinner, 60\% FB $200 \mathrm{rpm}, 1.5 \mathrm{mph} \quad \mathrm{C}^{\mathrm{t}} \quad 70.1 \mathrm{a}$

Hand-thinned control, 35 DAFB - $\quad 63.1 \mathrm{~b}$

$25.7 \mathrm{~b} \quad 24.2 \mathrm{~b}$

$20.6 \mathrm{a} \quad 16.4 \mathrm{a}$

$19.8 \mathrm{a} \quad 13.4 \mathrm{~b}$

'Late Ross' canning peach Quad V training, CA

String thinner, 80\% FB $185 \mathrm{rpm}, 1.5 \mathrm{mph}$

String thinner, $80 \%$ FB $200 \mathrm{rpm}, 2.0 \mathrm{mph}$

- 73.0

-

Hand-thinned control, 35 DAFB

- 50.0

$13.4-9.9$

$16.1 \quad 5.5$

$17.2 \quad 8.6$

$15.7 \quad 5.3$

'Saturn' peento peach Perpendicular V training, $P A$

String thinner, pink $150 \mathrm{rpm}, 1.8 \mathrm{mph} \quad 6.9 \mathrm{a} \quad 21.2 \mathrm{a}$

Hand-thinned control, 35 DAFB

$6.5 \mathrm{~b}$

$5.0 \mathrm{~b}$

$9.2 \mathrm{a}$

$2.0 \mathrm{a}$

$5.6 \mathrm{~b}$

$0.3 \mathrm{~b}$

'Grand Bright' nectarine Perpendicular V training, WA

String thinner, pink $225 \mathrm{rpm}, 3.0 \mathrm{mph}$

String thinner, 60\% FB $225 \mathrm{rpm}, 3.0 \mathrm{mph}$

String thinner, fruit set $225 \mathrm{rpm}, 3.0 \mathrm{mph}$

Hand-thinned control, FB

Hand-thinned control, 35 DAFB

String thinner, petal fall $200 \mathrm{rpm}, 1.8 \mathrm{mph}$

String thinner, petal fall $220 \mathrm{rpm}, 1.8 \mathrm{mph}$

Hand-thinned control, 35 DAFB

$\begin{array}{llll}7.2 \mathrm{a} & 51.7 \mathrm{a} & 15.6 \mathrm{~b} & 8.1 \mathrm{a} \\ 7.2 \mathrm{a} & 21.7 \mathrm{~b} & 19.8 \mathrm{a} & 4.3 \mathrm{~b} \\ 7.2 \mathrm{a} & 21.7 \mathrm{~b} & 14.5 \mathrm{~b} & 3.1 \mathrm{~b} \\ 7.1 \mathrm{a} & 10.0 \mathrm{~b} & 16.8 \mathrm{~b} & 1.7 \mathrm{~b} \\ 7.3 \mathrm{a} & 13.8 \mathrm{~b} & 15.5 \mathrm{~b} & 2.2 \mathrm{~b}\end{array}$

'Nesstar' fresh peach Quad V training, SC

$\begin{array}{llll}- & 57.0 \mathrm{a} & 7.8 \mathrm{a}^{\mathrm{q}} & 4.3 \mathrm{a} \\ - & 64.4 \mathrm{a} & 6.0 \mathrm{~b} & 2.9 \mathrm{~b} \\ - & 42.3 \mathrm{~b} & 8.3 \mathrm{ab} & 5.0 \mathrm{ab}\end{array}$

${ }^{2}$ String thinner was fitted with two rows of molded cords with alternating gaps; DAFB = days after full bloom before follow-up hand thinning, $\mathrm{FB}=$ full bloom, $1 \mathrm{mph}=1.6093$ $\mathrm{km} \cdot \mathrm{h}^{-1}$

$\mathrm{y} 1$ inch $=2.54 \mathrm{~cm}$

'Fruit diameter and packout distribution determined on 40 to 50 fruit harvested per treatment from each of six replicates ('Tuolumne', 'Loadel', 'Saturn', and 'Grand Bright').

For 'Late Ross' and 'Nesstar', fruit were graded at the processing and packing facility, respectively.

"Fruit from 'Tuolumne', 'Loadel', 'Late Ross', and 'Nesstar' plots weighed; other yields calculated from fruit counts and size distributions; 1 ton $/$ acre $=2.4711 \mathrm{~kg} \cdot$ ha ${ }^{-1}$.

"Marketable processing fruit are all fruit $\geq 2 \%$ inches (number 1 grade) plus up to $5 \%$ of fruit $2 \frac{1 / 4}{4}$ to $2 \frac{3}{8}$ inches (number 2 grade) with the exception of 'Loadel', which are

allowed up to $10 \%$ number 2 fruit. High market value fresh fruit are all fruit $\geq 3$ inches diameter, with the exception of peento peaches that are all fruit $\geq 23 / 4$ inches.

"Mean separation within columns and cultivars by Fisher's protected least significant difference at $P \leq 0.05$.

${ }^{\mathrm{t} N o}$ data available.

${ }^{s}$ Not replicated.

developed specifically for this research has been commercialized and will now be manufactured in North America, in addition to Germany.

\section{Literature cited}

Baugher, T.A., J. Schupp, K. Lesser, and K. Reichard. 2009. Horizontal string blossom thinner reduces labor input and increases fruit size in peach trees trained to open-center systems. HortTechnology 19:755-761.

Baugher, T.A., K.C. Elliott, B.D. Horton, S.S. Miller, and D.W. Leach. 1991. Improved methods of mechanically thinning peaches at full bloom. J. Amer. Soc. Hort. Sci. 116:766-769.

Berlage, A.G. and R.D. Langmo. 1982. Machine vs. hand thinning of peaches. Trans. Amer. Soc. Agr. Eng. 25:538-543.
Bertschinger, L., W. Stadler, F.P. Weibel, and R. Schumacher. 1998. New methods for an environmentally safe regulation of flower and fruit set and of alternate bearing of the apple crop. Acta Hort. 466:6570 .

Byers, R.E. 1990. Thin peaches with water. Amer. Fruit Grower 110:20-21.

Diezma, B. and U.A. Rosa. 2005. Monitoring of fruit removal for mechanical thinning of peaches. Frutic 5:12-16.

Glenn, D.M., D.L. Peterson, D. Giovannini, and M. Faust. 1994. Mechanical thinning of peaches is effective postbloom. HortScience 29:850-853.

Glozer, K. and J. Hasey. 2006. Mechanical thinning in cling peach. HortScience 41:995. (Abstr.).
Krawczyk, G. (ed.). 2010. 2010-2011 Pennsylvania tree fruit production guide. Penn State College Agr. Sci. Bul. AGRS045 .

Schupp, J.R., T. Auxt Baugher, S.S. Miller, R.M. Harsh, and K.M. Lesser. 2008. Mechanical thinning of peach and apple trees reduces labor input and increases fruit size. HortTechnology 18: $660-670$

U.S. Department of Agriculture. 2009. USDA agricultural marketing service report. USDA fruit and vegetable market news. 10 Dec. 2009. <http://marketnews.usda. gov/portal/fv?paf_dm=full\&paf_gear_id= 1200002\&startIndex = 1\&dr=1 \&rowDisplay Max $=25 \&$ rep Type $=$ termPriceDaily \&dr $=1 \&$ locName $=\&$ commAbr $=$ PCH\&commName $=$ PEACHES $>$. 